\title{
Visualization of the Long Thoracic Nerve using High-Resolution Sonography
}

\section{Visualisierung des Nervus thoracicus longus mittels hochauflösendem Ultraschall}

Authors

Affiliations
D. Lieba-Samal' ${ }^{1}$, J. Morgenbesser², T. Moritz², G. M. Gruber ${ }^{3}$, M. Bernathova², J. Michaud ${ }^{4}$, G. Bodner ${ }^{2}$

Neurology, Medical University of Vienna, Austria

Biomedical Imaging and Image-guide Therapy, Medical University of Vienna, Austria

Systematic Anatomy, Medical University of Vienna, Austria

Physiatry, Université de Montréal, Canada

\section{Key words}

- normal variants

- long thoracic nerve

- scapula alata

- shoulder pain

received 23.8.2013

accepted 18.1.2014

Bibliography

DOI http://dx.doi.org/

10.1055/s-0034-1366084

Published online: March 19, 2014

Ultraschall in Med 2015; 36:

264-269 ๑ Georg Thieme

Verlag KG Stuttgart - New York . ISSN 0172-4614

\section{Correspondence}

Dr. Doris Lieba-Samal

Dept. of Neurology, Medical

University of Vienna

Währinger Gürtel 18-20

1090 Wien

Austria

Tel.: ++ 43/1/404003117

Fax: ++ 43/1/404003141

doris.lieba-samal@

meduniwien.ac.at

\section{Abstract}

$\nabla$

Purpose: The long thoracic nerve (LTN) innervates the serratus anterior muscle (SA) which plays an important role in shoulder function. Evaluation of the LTN has so far been restricted to clinical assessment and partly electromyography and neurography. Progress of high-resolution ultrasound (HRUS) increasingly enables visualization of small peripheral nerves and their pathologies. We therefore aimed at (a) clarifying the possibility of visualization of the LTN from its origin to the most distal point in the supraclavicular region visible and (b) developing an ultrasound protocol for routine use. We further present two cases of patients with LTN pathology.

Methods: The study consisted of two parts: Part 1 included 4 non-enbalmed human bodies in whom the LTN $(n=8)$ was located and then marked by ink injection. Correct identification was confirmed by anatomical dissection. Part 2 included 20 healthy volunteers whose LTN $(n=40)$ was assessed independently by two radiologists. Identification of the LTN was defined as consensus in recorded images.

Results: LTN was clearly visible in all anatomical specimens and volunteers using HRUS and could be followed until the second slip of the serratus anterior muscle from the supraclavicular region. In anatomical specimens, dissection confirmed HRUS findings. For all volunteers, consensus was obtained. The mean nerve diameter was $1.6 \mathrm{~mm}$ \pm 0.3 (range $1.1-2.1 \mathrm{~mm}$ ) after the formation of the main trunk.

Discussion: We hereby confirm a reliable possibility of visualization of the LTN in anatomical specimens as well as in volunteers. We encourage HRUS of the LTN to be part of the diagnostic work-up in patients presenting with scapular winging, shoulder weakness or pain of unknown origin.

\section{Zusammenfassung \\ $\nabla$}

Ziel: Der Nervus thoracicus longus (LTN) innerviert den Musculus serratus anterior (SA), der eine wichtige Rolle für die Funktion des Schultergelenks spielt. Seine Evaluierung war bisher auf klinische Untersuchung und teilweise Elektroneurografie und Elektromyografie beschränkt. Der Fortschritt des hochauflösenden Ultraschalls (HRUS) ermöglicht zunehmend die Darstellung kleiner peripherer Nerven und deren Pathologien. Ziel der vorliegenden Arbeit war es (a) die Visualisierbarkeit des LTN vom Ursprung bis zum distalsten einsehbaren Punkt supraklavikulär zu dokumentieren und (b) ein Ultraschallprotokoll für den Routineeinsatz zu erstellen. Darüber hinaus präsentieren wir zwei Fälle mit LTN-Pathologien.

Material und Methoden: Die Studie bestand aus zwei Teilen: Teil 1 umfasste die Ultraschalldarstellung des LTN, seine Markierung mittels Tinte und anschließende Sektion in 4 frischen anatomischen Präparaten $(n=8)$. Teil 2 umfasste die Darstellung des LTN in 20 gesunden Freiwilligen $(n=40)$. Die Identifikation erfolgte im Konsens durch zwei Untersucher.

Ergebnisse: Der LTN konnte in allen anatomischen Präparaten und Probanden identifiziert werden. Die Darstellung von supraklavikulär aus gelang bis zur zweiten Zacke des SA. Die korrekte Identifikation wurde in den Präparaten durch Dissektion bestätigt. Für alle Probanden wurde Konsens erzielt. Der durchschnittliche Durchmesser des LTN lag bei $1,6 \mathrm{~mm} \pm 0,3$ (Range 1,1-2,1 mm) nach der Formierung des Hauptstammes.

Schlussfolgerung: Die Ergebnisse dieser Studie bestätigen die zuverlässige Visualisierbarkeit des LTN mittels HRUS und legen den zukünftigen routinemäßigen Einsatz in der Diagnostik bei PatientInnen mit Scapula alata, Schwäche oder Schmerzen unklarer Genese im Schultergelenk nahe. 


\section{Introduction}

\section{$\nabla$}

The long thoracic nerve (LTN) mainly originates from the C5 to C7 nerve roots, occasionally also involving the $\mathrm{C} 4$ and $\mathrm{C} 8$ roots [1 -4]. In most cases, the C5 and C6 roots unite to form a superior trunk at the height of the interscalene spatium, before unifying with the $C 7$ root (also called the inferior trunk)[1 -4]. The nerve trunk travels down posteriorly to the brachial plexus and onward on the surface of the serratus anterior muscle (SA), innervating each of its digits ( $\bullet$ Fig. 1) [3]. The SA is a key player in shoulder stabilization during arm elevation, ensuring fixation and upward rotation of the scapula [5-7]. The classical clinical picture of its palsy is scapular winging [8], accompanied by pain in the ipsilateral shoulder caused by malrotation [9-13] and the inability of arm elevation above $100^{\circ}[10,13]$. Various reasons for LTN palsy have been described, among them traumatic or sports-related [9, $12-14]$, iatrogenic injury during axillary lymph node resection or resection of the first rib[14-18], involvement in Parsonage-Turner-Syndrome $[19,20]$, a tumor [21] or idiopathic palsy [13, $22-24]$.

Evaluation of the LTN thus far has been restricted to the clinical picture and findings in electromyography, which is invasive, painful, and sometimes inconclusive. Moreover, it involves the

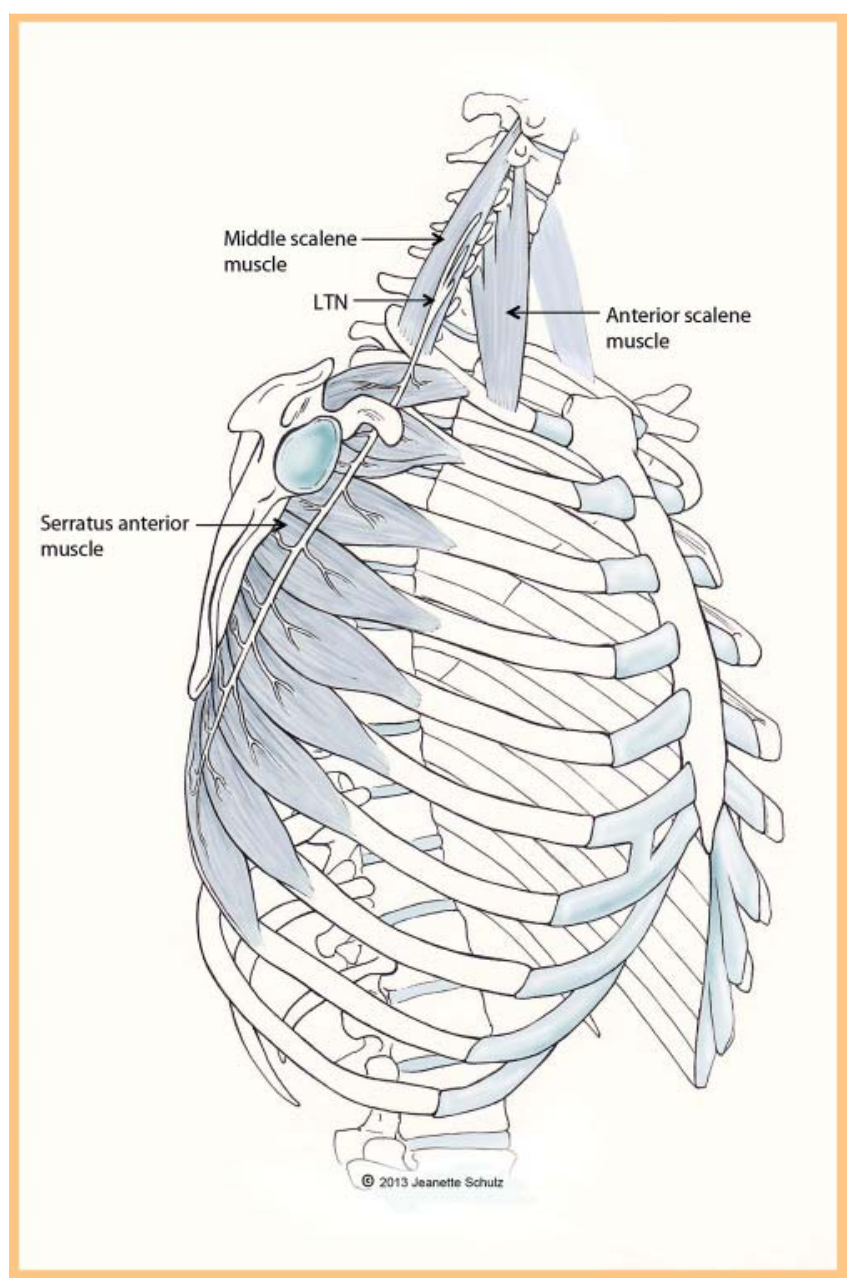

Fig. 1 Illustration of the course of the LTN, with kind permssion of Jeanette Schulz.

Abb. 1 Illustration des Verlaufs des LTN, mit freundlicher Genehmigung von Jeanette Schulz. risk of iatrogenic pneumothorax and should, therefore, only be carried out by very experienced investigators [25]. This anatomical constellation creates a significant demand for reliable imaging techniques in the assessment of these patients. However, until now only MR imaging has been proposed as a feasible method for demonstrating signs of denervation in the SA and thus, indirect manifestations of LTN injury [26], without any published studies conducted that clarify the actual value of MR imaging in this context.

High-resolution ultrasound (HRUS) is another option. High-frequency linear probes offer excellent tissue differentiation, but come with the disadvantage of reduced tissue penetration. This, however, makes them ideal for the examination of superficial structures - which applies to the LTN for the majority of its course with the exception of the part behind the clavicle, where it lies deep and behind the bony structures. While visualization of its proximally adjacent structure, the brachial plexus, is routinely used therapeutically for regional anesthesia [27-29], the same has, as yet, only been described once for the LTN: Hanson et al. systematically looked for visible segments of the LTN and dorsal scapular nerve posterior to the brachial plexus in 50 subjects referred for shoulder surgery and identified the dorsal scapular nerve in $77 \%$ and the LTN in $23 \%$ [30]. As the LTN is formed by the $\mathrm{C} 5$-C7 ventral nerve roots as mentioned above and its diameter was described as approximately $2 \mathrm{~mm}$ [3], visualization of the LTN with high-resolution probes should be possible.

This study aimed at defining (a) the possibility of visualization of the LTN from its origin to the most distal point visible from the supraclavicular region by HRUS and (b) the establishment of an ultrasound protocol with identification of ultrasound landmarks, which could be of use for the diagnostic work-up of probable neuropathy of the LTN in the future.

\section{Methods}

\section{Subjects}

This study consisted of two parts: Part 1 included four non-embalmed human anatomic specimens in legal custody of the Department of Anatomy, Medical University of Vienna. After HRUS identification and tracing of the LTN, it was marked with ink and consecutive dissection was performed to confirm HRUS findings. Attention was turned to identification of ultrasound and correlating anatomic landmarks for the establishment of a practically applicable ultrasound protocol. Part 2 included 20 healthy volunteers, who were recruited via notices at the Medical University of Vienna. If interested, they contacted the Department of Radiology and were given an information sheet, which had to be signed before the examination. The local ethics committee approved this study.

\section{Ultrasound examination}

HRUS examinations were performed using a GE Logic E9 ultrasound platform with high-frequency probes (GE ML 6-15-D, L 8 -18i-D). All examinations were carried out by two examiners experienced in peripheral nerve ultrasound, following a standardized assessment protocol, which started at the cervical roots towards the interscalene triangle and then traced the LTN downward as far as possible from the supraclavicular region. As reference landmarks, the middle scalene muscle and the transverse tubercles from C5 to C7 were used. Examinations were documented using both still images and dynamic video sequen- 

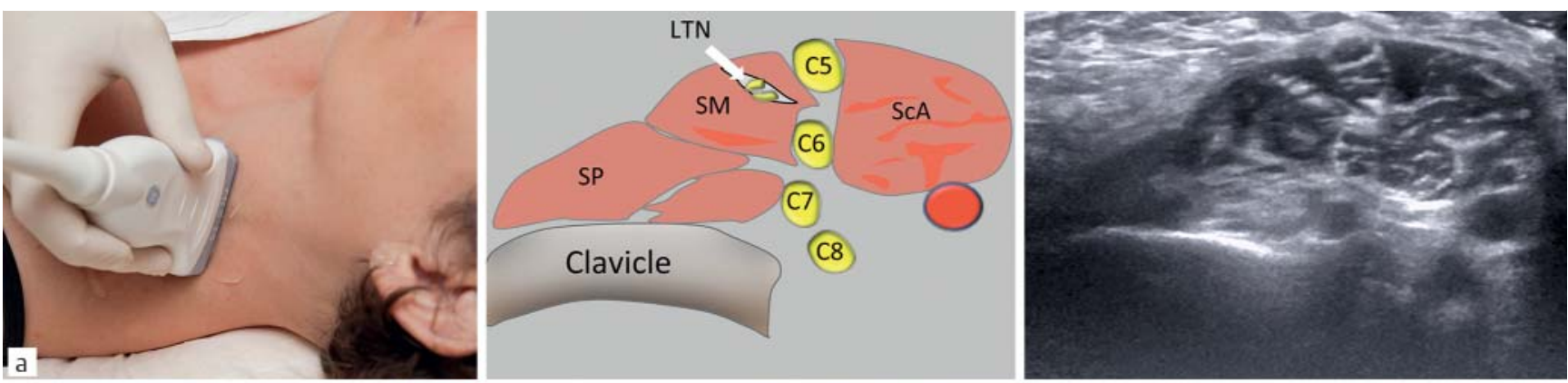
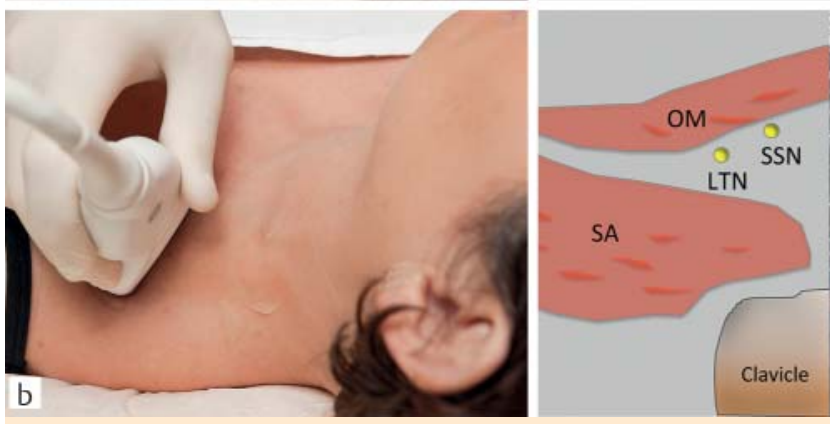

Fig. 2 a Example of sonographic finding of the LTN within the interscalene triangle in ventromedial transverse view (Abbreviations used: $\mathrm{C} 5-\mathrm{C} 8=$ cervical roots, $\mathrm{ScA}=$ anterior scalene muscle, $\mathrm{SM}=$ middle scalene muscle, $\mathrm{SP}=$ posterior scalene muscle); $\mathbf{b}$ Example of sonographic finding at the most distal point visible from the supraclavicular region (Abbreviations used: $\mathrm{OM}=$ omohyoid muscle, $\mathrm{SA}=$ Serratus anterior muscle, SSN = suprascapular nerve).

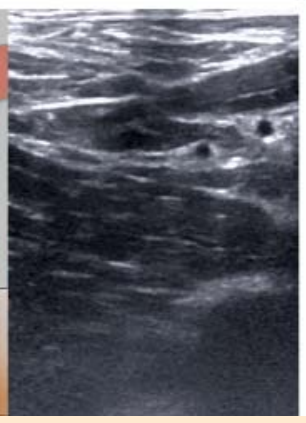

Abb.2 a Beispiel eines sonografischen Befundes des LTN auf Höhe des Durchtritts durch die Mm. scaleni (ventromedial transversal) (Abkürzungen: $\mathrm{C} 5-8=$ cervikale Wurzeln, $\mathrm{ScA}=\mathrm{M}$. scalenus anterior, $\mathrm{SM}=\mathrm{M}$. scalenus medius, $\mathrm{SP}=\mathrm{M}$. scalenus posterior); $\mathbf{b}$ Beispiel eines sonografischen Befundes des LTN auf Höhe des distalsten einsehbaren Punktes von supraklavikulär (Abkürzungen: $\mathrm{OM}=\mathrm{M}$. omohyoideus, $\mathrm{SA}=\mathrm{M}$. serratus anterior, $\mathrm{SSN}=\mathrm{N}$. suprascapularis). ces. Identification of the LTN was defined as consensus between the two examiners.

\section{Evaluation}

Measurements of the LTN in healthy volunteers were performed at the most distal point visible from the supraclavicular region, after the formation of the main trunk, using the measurement tool included in the local PACS (Picture Archiving and Communication System; Impax Client ES, Version 5302, AGFA Healthcare, Mortsel, Belgium).

Descriptive statistics were performed with SPSS Statistics, Version 19 (IBM SPSS Statistics, (c) SPSS Inc. 1989, 2010). Metric data are given as mean \pm standard deviation.

\section{Results}

\section{Ultrasound protocol}

The LTN was clearly visible in all four cadavers and all 20 volunteers on both sides at the intramuscular scalene level and could be followed down to the first or second slip of the SA.

The ultrasound technique that was determined to be the most comprehensive was as follows: Starting from the midline at the height of the thyroid gland in the transverse view, the probe was moved laterally until the anterior and the middle scalene muscle at the C5 and C6 levels were identified. Then, by moving the probe cranially and caudally, we searched for a hyperechoic fascial line running within the middle scalene muscle. Within this fascia, nerve tissue consists of ramifications of the C5 and C6 roots, converging to the main LTN ( $\bullet$ Fig. 2a). Roots were fol- lowed proximally to ensure origin from C5 and C6, thereby avoiding confusion with the dorsal scapular nerve, which originates from C3-C5. Then the LTN was followed distally. In two of the cadaveric nerves and $28 \%(11 / 40)$ of the LTNs in volunteers, fibers from the C7 root were also detectable in the LTN. The common trunk was detectable on the first two slips of the SA ( $\bullet$ Fig. 2b).

Dissection confirmed correct ultrasound identification of the nerve in all four anatomical specimens $(n=8)$ at proximal (scalene level) and distal (most distal point visible from the supraclavicular region) sites. An example of a dissection finding is shown in 0 Fig. 3.

In volunteers (11 male/9 female, aged $21-40$ ), consensus was obtained between the two examiners in all 20 volunteers $(n=40)$ at the proximal site of identification. The mean transverse diameter of the LTN after formation of the main trunk was of $1.6 \mathrm{~mm} \pm 0.3(1.3-2.1)$ in volunteers. In addition, we assessed the maximal cross-sectional diameter (MCSD) of each branch of the cervical roots contributing to the LTN: C5 $0.8 \mathrm{~mm} \pm 0.2$, C6 $1.1 \mathrm{~mm} \pm 0.3$ and $\mathrm{C} 70.7 \mathrm{~mm} \pm 0.1$ ( $\bullet$ Tab. 1 )

\section{Cases of LTN pathology}

Case 1

A 45-year-old male had a common cold, which was followed by strong pain in the right shoulder radiating toward the scapula. After some days he was unable to lift his right arm. Clinical examination showed a scapula alata on the right side. Sonographic assessment was carried out two months after the onset of symptoms and revealed a thickened LTN on the right side compared to the left ( Fig. 4) and an atrophic SA on the right side. Electromyography confirmed these findings by showing a chronic neurogenic lesioning pattern. 

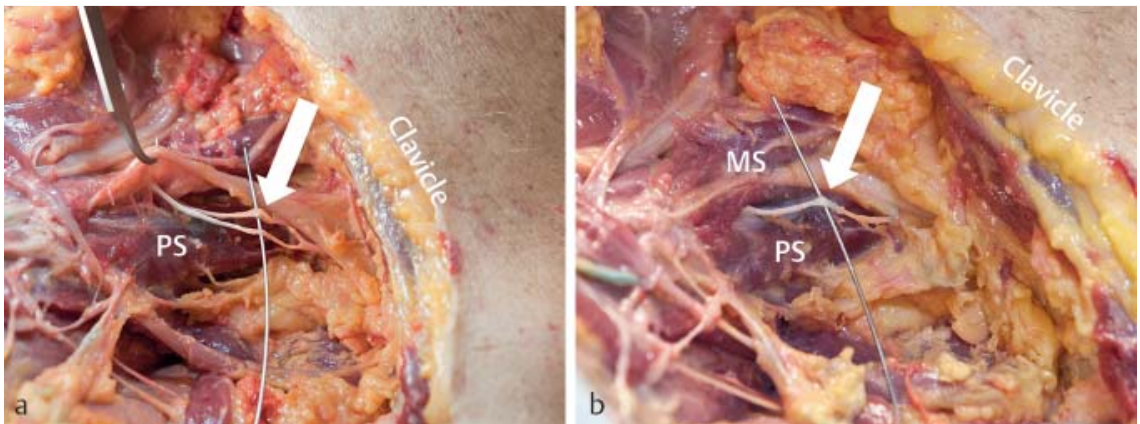

Fig. 3 a Example of finding in dissections after marking of the LTN (white arrow) at proximal site (also showing union of $\mathrm{C} 5$ and $\mathrm{C} 6$ cervical roots) (Abbreviation used: PS = posterior scalene muscle); $\mathbf{b}$ Example of finding in dissections after marking of the LTN (white arrow) at the most distal point visible from the supraclavicular region (Abbreviations used: $\mathrm{MS}=$ middle scalene muscle, $\mathrm{PS}=$ posterior scalene muscle).

Table 1 Measures of maximal cross-sectional diameter of cervical roots forming the LTN ( $C 5, C 6$ and $C 7)$ and after formation of the main trunk at the most distal point visible in healthy volunteers (given in $\mathrm{mm}$ ).

\begin{tabular}{|cllllllllll}
\hline \multicolumn{1}{|c}{} & \multicolumn{3}{c}{ right } & & \multicolumn{7}{c}{ left } \\
\hline no. & gender & age & C5 & C6 & C7 & trunk & C5 & C6 & C7 & trunk \\
\hline 1 & M & 25 & 0.5 & 0.7 & 0.9 & 1.4 & 0.6 & 0.9 & & 1.3 \\
\hline 2 & $\mathrm{~F}$ & 24 & 0.7 & 0.9 & & 1.7 & 0.8 & 1.0 & & 1.8 \\
\hline 3 & $\mathrm{~F}$ & 23 & 0.5 & 0.8 & 0.8 & 1.5 & 0.6 & 1.2 & & 1.7 \\
\hline 4 & $\mathrm{M}$ & 24 & & 1.1 & & 1.7 & 1.0 & 1.4 & 0.6 & 1.8 \\
\hline 5 & $\mathrm{~F}$ & 24 & 0.6 & 1.6 & & 2.0 & 0.8 & 1.5 & & 2.1 \\
\hline 6 & $\mathrm{M}$ & 22 & 0.9 & 1.8 & & 1.9 & 1.0 & 1.4 & 0.6 & 1.8 \\
\hline 7 & $\mathrm{~F}$ & 27 & 1.0 & 1.3 & 0.7 & 1.9 & 1.0 & 1.4 & 0.6 & 1.8 \\
\hline 8 & $\mathrm{~F}$ & 25 & 0.7 & 1.2 & & 1.8 & 0.7 & 1.1 & & 1.9 \\
\hline 9 & $\mathrm{M}$ & 29 & 0.8 & 1.2 & & 1.5 & 0.8 & 1.4 & & 1.7 \\
\hline 10 & $\mathrm{M}$ & 21 & 0.6 & 1.1 & 0.8 & 1.4 & 0.8 & 1.3 & 0.6 & 1.7 \\
\hline 11 & $\mathrm{M}$ & 29 & 0.9 & 1 & & 1.2 & 0.9 & 0.8 & & 1.6 \\
\hline 12 & $\mathrm{M}$ & 25 & 0.8 & 1 & & 1.2 & 0.7 & 0.9 & & 1.3 \\
\hline 13 & $\mathrm{M}$ & 40 & 1.0 & 1.4 & & 1.7 & 0.6 & 1.1 & & 1.8 \\
\hline 14 & $\mathrm{~F}$ & 31 & 0.6 & 0.7 & & 1.3 & 0.5 & 0.9 & & 1.1 \\
\hline 15 & $\mathrm{~F}$ & 30 & 1.1 & 0.9 & & 1.3 & 1.0 & 1.0 & & 1.4 \\
\hline 16 & $\mathrm{~F}$ & 35 & 1.0 & 1.1 & & 1.6 & 0.6 & 1.0 & 0.8 & 1.4 \\
\hline 17 & $\mathrm{M}$ & 33 & 0.8 & 1.3 & & 1.7 & & 1.3 & & 1.3 \\
\hline 18 & $\mathrm{M}$ & 31 & 1.3 & 1.4 & & 1.9 & 0.8 & 1.3 & 0.6 & 1.5 \\
\hline 19 & $\mathrm{M}$ & 30 & 1.1 & 1.3 & & 1.5 & 1.1 & 1.1 & & 1.3 \\
\hline 20 & $\mathrm{~F}$ & 40 & 0.8 & 1.1 & & 1.5 & 0.8 & 0.8 & 0.9 & 1.7 \\
\hline & & & & & & & & \\
\hline
\end{tabular}

\section{Case 2}

A 48-year-old male with no known health problems was getting out of his truck (1.5 - 2 meters high). His feet slipped on ice on the small ladder of the truck. To prevent his fall, he gripped a handle with his right hand and hung suspended for a few seconds by one hand with his full body weight $(80 \mathrm{~kg})$. During the subsequent days he developed pain in the lateral neck radiating to the lateral thoracic area and experienced weakness upon elevation of the upper extremity. Clinical examination showed a scapula alata and LTN lesioning was documented on EMG. Sonographic assessment revealed an enlarged LTN on the symptomatic side compared to the non-symptomatic side, at the height of the interscalene triangle ( $\bullet$ Fig. 5.). Considering the anamnesis, this was assumed to correspond to a traction neuroma of the LTN.
Abb.3 a Beispiel eines Ergebnisses nach sonografischer Markierung des LTN (weißer Pfeil) und anschließender Sektion im proximalen Abschnitt (mit Vereinigung der Nervenwurzeln $\mathrm{C} 5$ und C6) (Abkürzung: $\mathrm{PS}=\mathrm{M}$. scalenus posterior); b Beispiel eines Ergebnisses nach sonografischer Markierung des LTN (weißer Pfeil) und anschließender Sektion im disalsten einsehbaren Punkt von supraklavikulär (Abkürzungen: $\mathrm{MS}=\mathrm{M}$. scalenus medius, $\mathrm{PS}=$ M. scalenus posterior). unification of the $\mathrm{C} 5$ and $\mathrm{C} 6$ fibers in the proximity of the scalene muscles down to the first or second slip of the SA.

A contribution of the C7 root to the LTN was found in $28 \%$ of volunteers and $20 \%$ of anatomical specimens. Unification of the superior trunk of the LTN, consisting of C5 and C6 ventral roots with an inferior trunk consisting of the $\mathrm{C} 7$ root, would have been expected in around three-fourths of cases according to existing anatomical research [1 -4]. While pure chance cannot be excluded due to our rather small sample size, one possible other explanation could be that $\mathrm{C} 7$ was described as being an average of $40 \%$ thinner than C5 and C6 [3], and might, therefore, be missed.

Ultrasound measurements revealed somewhat lower values than described previously in anatomical studies. In our study, the MCSD was $1.6 \mathrm{~mm} \pm 0.3$, while Wang et al. [3] described $2.27 \mathrm{~mm} \pm 0.39$ and Tubbs et al. [2] reported $3 \mathrm{~mm} \pm 2.5$. 


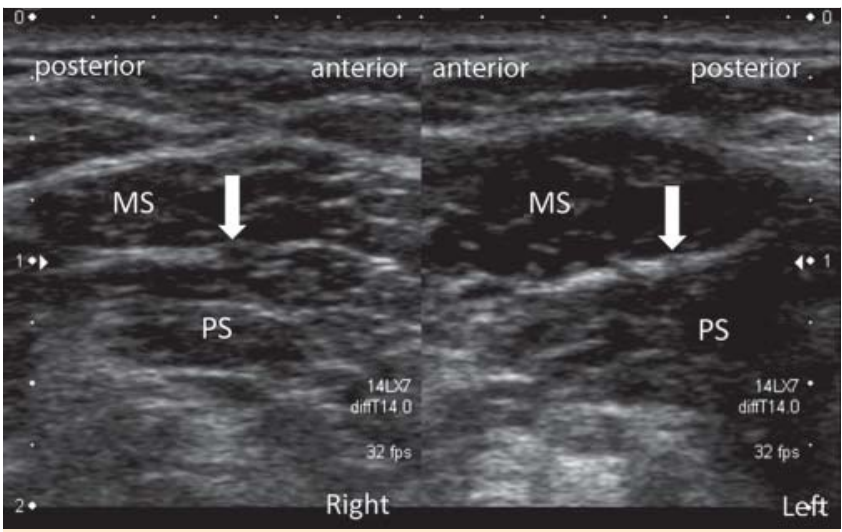

Fig. 5 Sonographic findings in case 2 showing an enlargement of the right LTN (white arrows) at the height of the interscalene triangle, considered to correspond to a traction neuroma of the LTN (Abbreviations: MS = middle scalene muscle, $\mathrm{PS}$ = posterior scalene muscle).

Abb. 5 Sonografischer Befund des zweiten Patienten: Vergrößerung des rechten LTN (weiße Pfeile) auf Höhe der Mm. scaleni, interpretiert als Traktionsneurom des LTN (Abkürzungen: MS = M. scalenus medius, $\mathrm{PS}=\mathrm{M}$. scalenus posterior)

As Wang and Tubbs presented data derived from formalin-fixed anatomical specimens, while we measured LTN in young, healthy volunteers, findings might, not be directly comparable.

In our rather homologously distributed group in terms of age and health status, we found a variation of the MCSD of $90 \%$ of the main trunk (between 1.1 and $2.1 \mathrm{~mm}$ ). We believe that establishing of normative values is hardly possible, and we, therefore, encourage comparison of sides for assessment. This is also illustrated by the first case presented, where the MCSD was $1.7 \mathrm{~mm}$ on the affected and $1.0 \mathrm{~mm}$ on the healthy side - both of which are below the MCSD of $2.1 \mathrm{~mm}$ assessed in healthy volunteers.

As the LTN is a small structure, we think that assessment of the MCSD for intraindividual comparison should be used rather than the cross-sectional area, which could be expected to carry a high measurement error.

In our opinion, HRUS will offer new possibilities for diagnosing LTN impairment. In addition to the post-infectious etiology, which we presumed was the case in Patient 1, and direct local trauma by e. g. iatrogenic lesioning in axilla dissection and thoracotomy, there are two main presumed mechanisms that cause LTN damage. The first is traction trauma, especially during arm elevation and head turn to the contralateral side (which was the case with Patient 2). The second is compression within the interscalene triangle or - when passing directly through the muscle within the middle scalene muscle.

Considering the first mechanism, we can only speculate about the value of HRUS and possible findings of traction neuromas [31]. The latter mechanism we would expect to demonstrate the same ultrasound appearance as compression syndromes throughout the body, with a marked, circumscribed reduction of caliber, associated with distal and/or proximal swelling. This idea is strengthened by observations from Nath et al. [32], who reported a series of 47 patients with scapular winging of various origins. From patient histories they concluded that nerve continuity should actually be preserved and as LTN palsy occurred during exercise in the vast majority of patients (79\%), they hypothesized that contraction of the middle scalene muscle and consecutive LTN compression could be the cause. During consecutive decompression and microneurolysis, they reported that $94 \%$ of all nerves showed demarcated areas of compression, more so towards the point of exit from the muscle. As HRUS is well established for the assessment of nerve entrapment syndromes [33, 34], we believe that following our proposed examination protocol for ultrasound of the LTN will facilitate and assure accurate diagnosis of LTN neuropathy and encourage its use as a standard procedure when evaluating patients with scapular winging.

This study has several strengths and limitations. Its strengths include the first time use of HRUS for specific assessment of the LTN and confirmation of the findings by the gold standard of anatomical dissection. Its limitations include that findings in-vivo were uncontrolled by not applying electrical stimulation and thereby confirming findings in volunteers. However, reliability in anatomical specimens was $100 \%$ and LTN in volunteers was followed proximally and distally to avoid confusion with other nerve tissue in the proximity.

In conclusion, we consider HRUS a valuable tool for the assessment of the LTN within the supraclavicular region and strongly encourage its use. Further studies are needed to assess the value of ultrasound in diagnosing LTN palsy.

\section{References}

1 Bertelli JA, Ghizoni MF. Long thoracic nerve: anatomy and functional assessment. J Bone Joint Surg Am 2005; 87: 993-998. DOI: 10.2106/ JBJS.D.02383

2 Tubbs RS, Salter EG, Custis JW et al. Surgical anatomy of the cervical and infraclavicular parts of the long thoracic nerve. J Neurosurg 2006; 104: 792 - 795 . DOI: 10.3171/jns.2006.104.5.792

3 Wang JF, Dang RS, Wang $D$ et al. Observation and measurements of long thoracic nerve: a cadaver study and clinical consideration. Surg Radiol Anat 2008; 30: 569-573 . DOI: 10.1007/s00276-008-0368-8

4 Yazar F, Kilic C, Acar HI et al. The long thoracic nerve: Its origin, branches, and relationship to the middle scalene muscle. Clin Anat 2009; 22: 476 - 480. DOI: $10.1002 /$ ca.20794

5 Dvir Z, Berme $N$. The shoulder complex in elevation of the arm: a mechanism approach. J Biomech 1978; 11: 219-225

6 Eisler P. Die Muskeln des Stammes. Fischer; 1912

7 Hamada J, Igarashi E, Akita $\mathrm{K}$ et al. A cadaveric study of the serratus anterior muscle and the long thoracic nerve. J Shoulder Elbow Surg 2008; 17: 790 - 794. DOI: 10.1016/j.jse.2008.02.009

8 Martin RM, Fish DE. Scapular winging: anatomical review, diagnosis, and treatments. Curr Rev Musculoskelet Med 2008; 1: 1-11. DOI: $10.1007 / \mathrm{s} 12178-007-9000-5$

9 Foo $C L$, Swann M. Isolated paralysis of the serratus anterior. A report of 20 cases. J Bone Joint Surg Br 1983; 65: 552 - 556

10 Gregg JR, Labosky D, Harty $M$ et al. Serratus anterior paralysis in the young athlete. J Bone Joint Surg Am 1979; 61: 825-832

11 Johnson JT, Kendall HO. Isolated paralysis of the serratus anterior muscle. J Bone Joint Surg Am 1955; 37-A: 567-574

12 Saeed MA, Gatens PF Jr, Singh S. Winging of the scapula. Am Fam Physician 1981; 24: 139-143

13 Wiater JM, Flatow EL. Long thoracic nerve injury. Clin Orthop Relat Res 1999: 17-27

14 Martin JT. Postoperative isolated dysfunction of the long thoracic nerve: a rare entity of uncertain etiology. Anesth Analg 1989; 69: $614-619$

15 Wood VE, Frykman GK. Winging of the scapula as a complication of first rib resection: a report of six cases. Clin Orthop Relat Res 1980: 160163

16 Oware A, Herskovitz S, Berger AR. Long thoracic nerve palsy following cervical chiropractic manipulation. Muscle Nerve 1995; 18: 1351

17 Kauppila LI, Vastamaki M. Iatrogenic serratus anterior paralysis. Longterm outcome in 26 patients. Chest 1996; 109: 31 - 34

18 Duncan MA, Lotze MT, Gerber LH et al. Incidence, recovery, and management of serratus anterior muscle palsy after axillary node dissection. Phys Ther 1983; 63: 1243-1247

19 Sumner AJ. Idiopathic brachial neuritis. Neurosurgery 2009; 65: A150 - A152. DOI: 10.1227/01.NEU.0000345355.59438.D1 
20 van Alfen $N$. Clinical and pathophysiological concepts of neuralgic amyotrophy. Nat Rev Neurol 2011; 7: 315 -322. DOI: 10.1038/nrneurol.2011.62

21 Toshkezi G, Dejesus J, Jabre JF et al. Long thoracic neuropathy caused by an apical pulmonary tumor. J Neurosurg 2009; 110: 754-757. DOI: $10.3171 / 2008.10 . J N S 08755$

22 Petrera JE, Trojaborg $W$. Conduction studies of the long thoracic nerve in serratus anterior palsy of different etiology. Neurology 1984; 34 : $1033-1037$

23 Goodman CE, Kenrick MM, Blum MV. Long thoracic nerve palsy: a follow-up study. Arch Phys Med Rehabil 1975; 56: 352 - 358

24 Fardin P, Negrin P, Dainese R. The isolated paralysis of the serratus anterior muscle: clinical and electromyographical follow-up of 10 cases. Electromyogr Clin Neurophysiol 1978; 18: 379-386

25 Läsionen peripherer Nerven und radikuläre Syndrom. 8 ed. Mumenthaler M, Stöhr M, Müller-Vahl H ed Stuttgart: Thieme; 2003

26 Martinoli C, Gandolfo N, Perez MM et al. Brachial plexus and nerves about the shoulder. Semin Musculoskelet Radiol 2010; 14: 523-546. DOI: $10.1055 / \mathrm{s}-0030-1268072$

27 Koscielniak-Nielsen ZJ, Dahl JB. Ultrasound-guided peripheral nerve blockade of the upper extremity. Curr Opin Anaesthesiol 2012; 25: 253-259. DOI: 10.1097/ACO.0b013e32835069c2
28 Vermeylen $K$, Engelen S, Sermeus L et al. Supraclavicular brachial plexus blocks: review and current practice. Acta Anaesthesiol Belg 2012; 63: $15-21$

29 Halaszynski TM. Ultrasound brachial plexus anesthesia and analgesia for upper extremity surgery: essentials of our current understanding, 2011. Curr Opin Anaesthesiol 2011; 24: 581-591. DOI: 10.1097/ ACO.0b013e32834aca03

30 Hanson NA, Auyong DB. Systematic Ultrasound Identification of the Dorsal Scapular and Long Thoracic Nerves During Interscalene Block. Reg Anesth Pain Med 2012; DOI: 10.1097/AAP.0b013e31826f0a63

31 High-Resolution Sonography of the Peripheral Nervous System. Baert AL ed Berlin Heidelberg: Springer-Verlag; 2010

32 Nath RK, Lyons AB, Bietz G. Microneurolysis and decompression of long thoracic nerve injury are effective in reversing scapular winging: longterm results in 50 cases. BMC Musculoskelet Disord 2007; 8: 25. DOI: 10.1186/1471-2474-8-25

33 Bianchi S. Ultrasound of the peripheral nerves. Joint Bone Spine 2008; 75: 643 -649. DOI: 10.1016/j.jbspin.2008.07.002

34 Koenig RW, Pedro MT, Heinen CP et al. High-resolution ultrasonography in evaluating peripheral nerve entrapment and trauma. Neurosurg Focus 2009; 26: E13. DOI: 10.3171/FOC.2009.26.2.E13 